\title{
IMPLEMENTATION OF THE MIND MAPPING MODEL WITH SCATTERGORIES GAME IN IMPROVING CREATIVITY AND LEARNING OUTCOMES IN NATIONAL EDUCATION MATERIALS
}

\author{
Sri Rahayu Pudjiastuti ${ }^{1)}$ \\ ${ }^{1)}$ STKIP Arrahmaniyah Depok, Depok, Indonesia \\ Corresponding Author: yayu.pudjiastuti@gmail.com
}

\begin{abstract}
This study aims to find the Application of the Mind Mapping Model with Game Scatterories in Improving Student Creativity and Learning Outcomes in the Indonesian Legislation Regulations Material in class VI of MI Nurul Huda Cimanggis Depok. The results obtained were the Application of the Mind Mapping Model with Game Scattergories, the first cycle by obtaining an average score of 69.22 , in the second cycle a score of 74.18 was obtained and in the third cycle the Application of the Mind Mapping Model with Game Scattergories managed to score 77,90 points and succeeded in increasing the Learning Outcomes variable in National Legislation Materials and Creativity in achieving student completeness. The conclusion of the study is the Application of the Mind Mapping Model with Game Scatterories has succeeded in improving Learning Outcomes in the Material of National Legislation Regulations and Creativity of Grade VI MI Nurul Huda Cimanggis Depok. The implication of the research is to make the results of research as a reference in developing students' creativity and the concept of national legislation can be used as a guide for behavior in life in families, schools and communities. Suggestions are intended for students, teachers, principals, governments, institutions and students so that the results of this study can be a reference in the development of learning models.
\end{abstract}

Keywords: mind mapping, game scattergories.

\section{INTRODUCTION}

The Mind Mapping model with Game Scatterories is a learning model that involves students' ability to speed up the game, the accuracy of answering concepts (the number of concepts successfully answered), accuracy, curiosity, initiative, risk taking, cooperation and tolerance.

Mind Mapping or Mind Maps is a method for learning the concepts discovered by Tony Buzan. Mind mapping is a creative, effective, and literal way to record thoughts [1].

Game Scattergories is a game looking for words or concepts to increase Linguistic-Verbal intelligence (thinking in words) (DeFoter [2]). This game is used to strengthen the resilience of understanding previous concepts through "mind mapping".

\section{Puzzle Concept (Unloading Concepts)}

Students put together the concept of teaching material so that they found a complete concept.

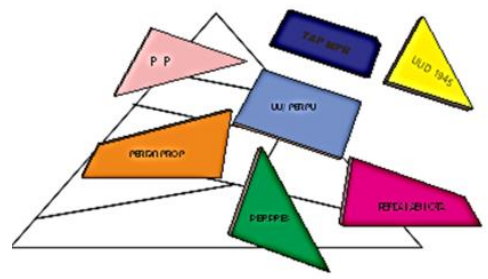

Figure 1. Example of Broken Triangle Compilation on Legislation Materials

Broken triangle is a learning model that uses visual media, because it involves the sense of sight. But it provides a pleasant effect to students in doing learning, because it is a learning activity while playing.

Game scattergories with word square, broken triangle and crossword puzzles encourage students to participate in the learning process activities, and actively become part of a group providing ideas and initiatives to conduct learning activities.

The Mind Mapping model with Game Scattergories is a learning model that involves students' ability to speed up the game, accuracy in answering concepts (number of concepts successfully answered), activeness, curiosity, initiative, risk taking, cooperation and tolerance.

Creativity is an experience in expressing and actualizing an individual's identity in an integrated form between self-relationship, nature and others (Munandar [3]).

Learning outcomes are an emphasis on potential skills or capacities possessed by a person, in the form of knowledge, thinking skills, and motor skills [2]..

According to Benjamin Bloom, learning outcomes are divided into three domains: 1) cognitive domain, 2) affective domain, 3) psychomotor domain (Sudjana [4]). 


\section{RESEARCH METHODS}

The study was conducted for 3 months, namely the middle of the odd semester of the 2017-2018 school year in class VI starting from October to December. The research method is a type of classroom action research. The informant was a grade VI student at MI Nurul Huda Cimanggis Depok with a total of 34 people, while the key informants were class VI teachers, a BK teacher, and a Religion teacher. The research instrument was a test used with the aim of obtaining data on Learning Outcomes in National Legislation Materials and observation sheets used to measure the Application of the Mind Mapping Model with Game Scattergories and Student Creativity. The validity of data is calibrated by interviews and field notes.

\section{RESULTS AND DISCUSSION}

To find out the progress or improvement achieved by a class action research in the first cycle, cycle II and cycle III, as well as knowing the level of success of research in an effort to improve Learning Outcomes National Legislation Material and Student Creativity through the Application of Mind Mapping Models with Scattergories Games can be presented to in the following table form:

Table 1. Comparison of Progress in Each Variable In Cycle I Research, Cycle II and Cycle III

\begin{tabular}{|c|c|c|c|c|}
\hline \multirow[t]{2}{*}{ No } & \multirow[t]{2}{*}{ Variables Researched } & \multicolumn{3}{|c|}{$\begin{array}{l}\text { Results of Achieving Each } \\
\text { Variable in Each Cycle }\end{array}$} \\
\hline & & I & II & III \\
\hline 1. & $\begin{array}{l}\text { Observation Results } \\
\text { for the Application of } \\
\text { the Mind Mapping } \\
\text { Model with } \\
\text { Scattergories Games }\end{array}$ & 69,22 & 74,18 & 77,90 \\
\hline 2. & $\begin{array}{l}\text { National legislative } \\
\text { material learning } \\
\text { outcomes }\end{array}$ & 68,00 & 73,82 & 84,85 \\
\hline 3. & $\begin{array}{l}\text { Student Creativity } \\
\text { Observation Results }\end{array}$ & 57,38 & 73,53 & 81,44 \\
\hline 4. & $\begin{array}{l}\text { Development of the } \\
\text { Learning Process }\end{array}$ & 74,58 & 84,17 & 94,17 \\
\hline & Jumlah & 269,18 & 305,7 & 338,36 \\
\hline & Rata-rata & 67,295 & 76,425 & 84,59 \\
\hline
\end{tabular}

Taking into account the table above, it turns out that from one aspect and three variables gradually increase in each cycle of action research.

Furthermore, the progress or improvement of each research cycle is illustrated in the following figure 2.

The results obtained from three variables are the Learning Outcomes in National Legislation Materials the first cycle gets points of 68.00 , then in the second cycle increases 5.82 points to 73.82 , while in the third cycle completeness is achieved by all students with the average success is 84.85 points. The score obtained is in the high category and is able to surpass the completeness set at 75. Student creativity, the first cycle gets an average score of 57.38 , then gets an increase of 15.45 points so that it gets a score of 73.53 , and at the end the third research or cycle score was 81.44 or it had exceeded the set standard of completion of 75. Application of the Mind Mapping Model With Game Scattergories, the first cycle by obtaining an average score of 69.22 , in the second cycle a score of 74 was obtained. 18 and in the third cycle the Application of the Mind Mapping Model with Game Scattergories succeeded in obtaining a score of 77.90 points and succeeded in increasing the Learning Outcomes variable in National Legislation Materials and Creativity in achieving students' completeness.

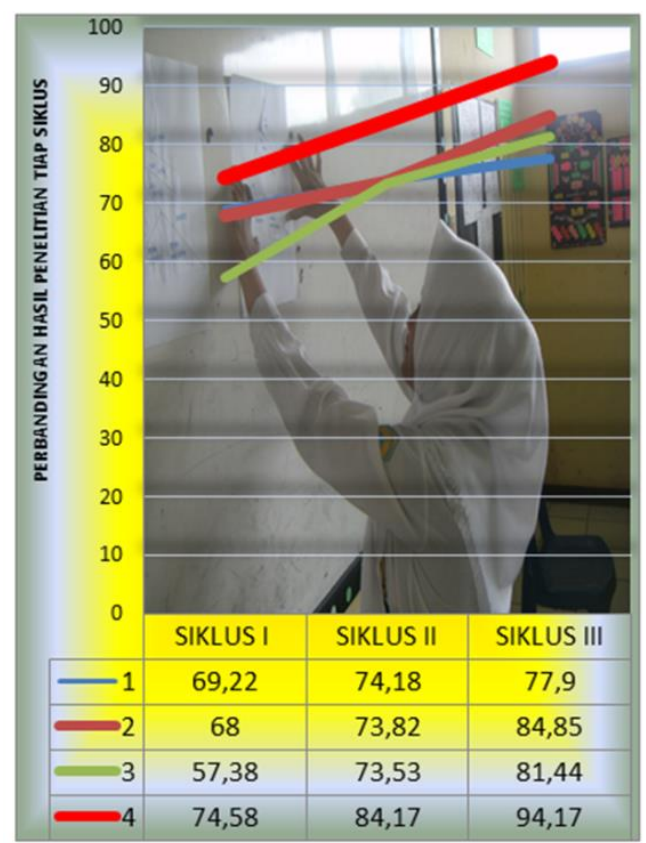

Figure.2. Progress Descriptions for Each Research Variable in Each Cycle Information :

1. Observation Results for the Application of the Mind Mapping Model with Scattergories Games

2. National legislative material learning outcomes

3. Student Creativity Observation Results

4. Development of the Learning Process

From all the data that has been obtained during the class action research process, it is known that significant progress has occurred in each cycle so that it has exceeded the targeted completeness. Thus the research carried out has undergone completeness with a high category and was declared to have success. 


\section{CONCLUSION}

The application of the Mind Mapping Model with Game Scatterories has succeeded in improving Learning Outcomes in National Legislative Material and Creativity of Grade VI students at MI Nurul Huda Cimanggis Depok. The implication of the research is to make the results of research as a reference in developing students' creativity and the concept of national legislation can be used as a guide for behavior in life in families, schools and communities.

\section{REFERENCES}

[1] Buzan. Tony, 2008. Buku Pintar Mind Map.Jakarta: Gramedia Pustaka Utama.. cet. 6.

[2] DeFoter, Bobbi, Mark Reardon dan Sarah SingerNouri. 2003. Quantum Teaching. Bandung : Mizan,.

[3] Munandar, Usc. 1998. Kreativitas Sepanjang Masa. Jakarta: Pustaka Sinar Harapan..

[4] Sudjana, Nana 2009. Penilaian Hasil Proses Belajar Mengajar. Bandung: Remaja Rosdakarya.. Cet. 13. 